\section{CURRENT} WORLD

ENVIRONMENT
ISSN: 0973-4929, Vol. 16, No. (3) 2021, Pg. 890-897

\section{Current World Environment}

www.cwejournal.org

\title{
Spatial and Temporal Assessment of Rainfall Variability using GIS Approach in Trichy District of Tamil Nadu
}

\author{
P. PONNUCHAKKAMMAL ${ }^{1}$, B. VIOLET JOY ${ }^{2}$, \\ P. ARAVIND ${ }^{3}$ and A. RAVIRAJ4*
}

\begin{abstract}
${ }^{1}$ Department of Soil and Water Conservation Engineering, AEC\&RI, TNAU, Kumulur, Trichy.
${ }^{2,3}$ Department of Soil and Water Conservation Engineering, Tamil Nadu Agricultural University,

Coimbatore-3.

${ }^{4}$ Tamil Nadu Agricultural University, Coimbatore-3.
\end{abstract}

\begin{abstract}
Precipitation is one of the transportation components in hydrological cycle. The magnitude of precipitation swings with time and space. Majorly India receives precipitation in the form of rainfall. Precipitation plays a key role in the rainfed agriculture. The present study deals with the rainfall characteristics of Tiruchirappalli district, Tamil Nadu. Seasonal rainfall data from eighteen rain gauge stations (1971-2012) have been taken for analysis of seasonal and annual rainfall pattern of Tiruchirappalli district. Mean rainfall of the district is about $696 \mathrm{~mm}$. The highest rainfall of $1247 \mathrm{~mm}$ recorded in the year 2005 and the lowest precipitation of $227 \mathrm{~mm}$ recorded in the year 1976. About 48 percent and 35 percent of the rainfall received in North East and South West Monsoon, respectively. Spatial rainfall distribution was studied with the help of Kriging interpolation technique and respective maps were prepared with Geographical Information System. The percentage departure of annual rainfall is classified under the category of excess, normal and large excess category. South East and central part of Tiruchirappalli receives moderate to low rainfall. North East parts of Tiruchirappalli district such as pullambadi, Lalgudi and nearby areas received maximum rainfall during North East Monsoon and South West Monsoon. In winter season Manapparai and Vaiyampatti region received more rainfall while in summer season Thottiam and Mayanur area received more rainfall. The two major highlighted crops in Trichy district are Banana and Onion. Tiruchirappalli district is one of the Banana growing belts in Tamil Nadu. Spatial distribution of rainfall maps will be helpful to form a crop plan for different crops to increase the agricultural productivity of Tiruchirappalli district and to ensure the food security.
\end{abstract}

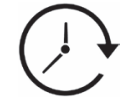

Article History

Received: 17 May 2021

Accepted: 30 November 2021

\section{Keywords}

Annual Distribution;

GIS;

Kriging;

Rainfall Variability;

Seasonal Distribution;

Tiruchirappalli.

CONTACT A. Raviraj $\gg$ Rraj@Tnau.ac.in 9 Tamil Nadu Agricultural University, Coimbatore-3

\section{(c) (i)}

(c) 2021 The Author(s). Published by Enviro Research Publishers.

This is an Open Access article licensed under a Creative Commons license: Attribution 4.0 International (CC-BY).

Doi: http://dx.doi.org/10.12944/CWE.16.3.19 


\section{Introduction}

Precipitation is the important component in a Hydrologic cycle and Precipitation plays an impactful role in maintaining the sustainability of resources in the earth. Precipitation generally deals with the Rainfall events only. Based on the intensity of rainfall, it is classified into three types viz., heavy $>7.5 \mathrm{~mm} / \mathrm{h}$, moderate - between 2.5 and $7.5 \mathrm{~mm} / \mathrm{h}$ and light rain - trace to $2.5 \mathrm{~mm} / \mathrm{h} .{ }^{1}$ The rainfall is one of the paramount factors affecting vegetation and accessibility of water resources. Rainfall is the major source of water to the agriculture especially in rainfed agriculture. Crop productivity mainly depends upon the characteristics of rainfall such as rainfall intensity, amount of rainfall received and distribution of rainfall over an area. Characteristics of rainfall change over time and from place to place. Analysis of the rainfall characteristics is important for planning of water harvesting structures and other conservation measures for ensuring sustainability. Rainfall is a pivotal agro-climatological factor in the seasonally parched region of the world and its assessment an important perquisite for agricultural management in India. ${ }^{2}$ Many studies have been conducted in different parts of India to predict the rainfall variability. ${ }^{3}$ The crop plan can be carried out through the weekly rainfall pattern to take the extension activities and it will help to increase the agricultural productivity. ${ }^{4}$ The climate of Tamil Nadu is generally wet subtropical climate and features fairly hot temperature over the year except during the monsoon season. Rainfall, groundwater, reservoir levels and crop conditions are the major factors to determine the nature and extent of drought conditions in Tamil Nadu.5 Contemporary studies have stated that each and every analysis of hydroclimatic elements should be done at the local scale rather than at a large or global scale.

In Tiruchirappalli district Banana and Onion are the top two ranked crops due to high water requirement for other crops. Banana is a succulent, evergreen and shallow rooted crop. It require more water for its higher production. Tiruchirappalli district is one of the Banana growing belts in Tamil Nadu. The district has an area of $7390 \mathrm{~km} 2$ (40.6\% of net sown area) underneath rainfed situation. Spatial distribution of rainfall maps will be helpful to prepare a crop plan for different crops to increase the agricultural productivity. Based on the availability of water resources, the crop selection like drought tolerant crop and management practices such as drip irrigation, mulching etc., can be followed to ensure the food security. Keeping in view the importance of rainfall in rainfed agriculture, the present study was made to understand the Tiruchirappalli district's rainfall characteristics.

\section{Methodology}

\section{Area of Interest}

Tiruchirappalli is one of the districts of Tamil Nadu state of India is sited in the central portion of Tamil Nadu (Fig 1) and the geographical extent of the Tiruchirappalli is 4403.83 Sq.km. For administrative purpose it was divided into 4 revenue Divisions, 11 Taluks and 507 Revenue Villages. Tiruchirappalli district experiences a tropical savanna climate and the average temperature is $28.8^{\circ} \mathrm{C}$ which varies from $25.3^{\circ} \mathrm{C}$ in winter season to $31.7^{\circ} \mathrm{C}$ in summer season. River Cauvery is the significant source for drinking and irrigation water requirement in the district. One twelth of the area of Trichy district is enclosed by means of hills and revenue forest. Pachamalai hill near Thuraiyur is the significant hill in this district. Main crops grown in the district are Ragi, Paddy, Onion, Groundnut, and pulses. The high priority cash crops in the district are Banana and Sugarcane.
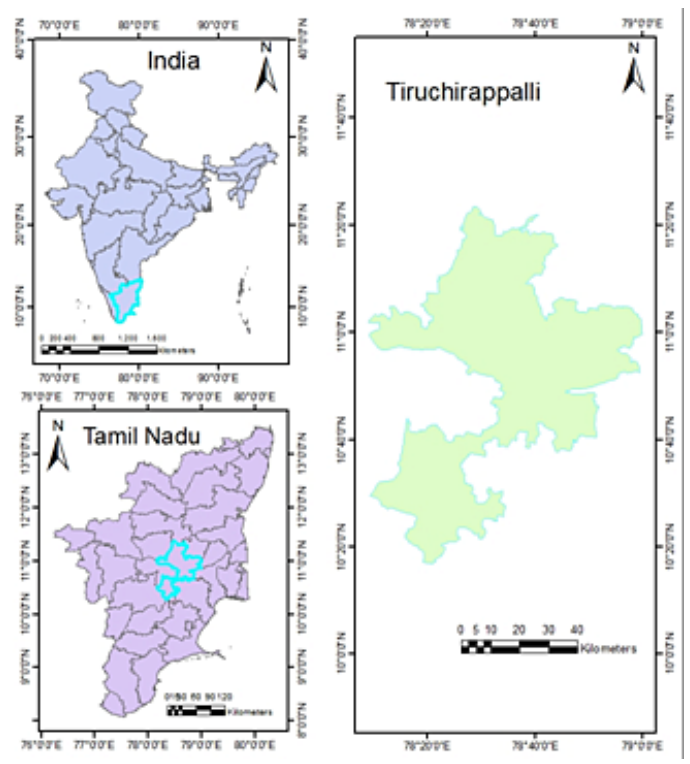

Fig. 1: Position of study region

\section{Data Collection}

Rainfall data of eighteen rain gauge stations for Tiruchirappalli district were (1971 to 2012 - 42 years) 
collected from the Public Work Department (PWD), Government of Tamil Nadu.

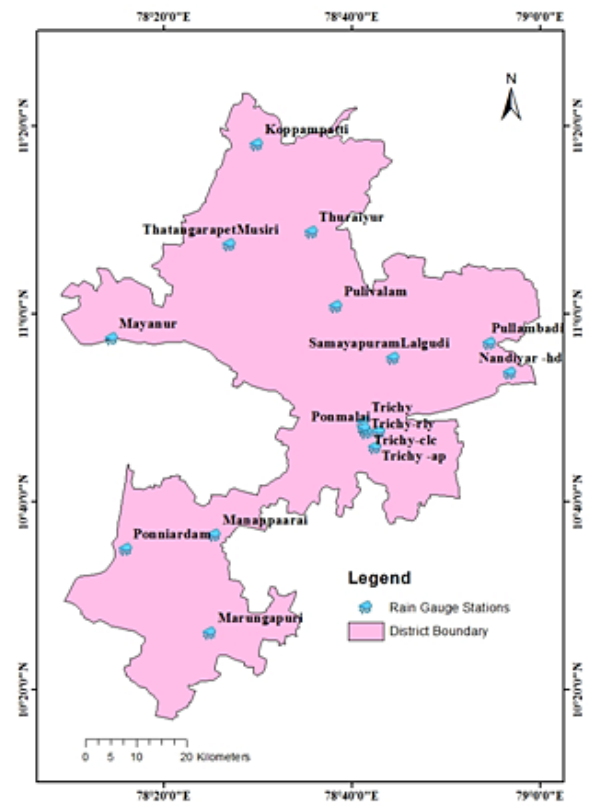

Fig. 2: Locus of rain gauge stations in Tiruchirapalli district

\section{Methodology of the study}

Seasonal and annual rainfall data was taken for analysis of rainfall pattern of Tiruchirappalli district. Eighteen rain gauge stations under the study are located in different parts of the district to observe the rainfall event (Fig 2).

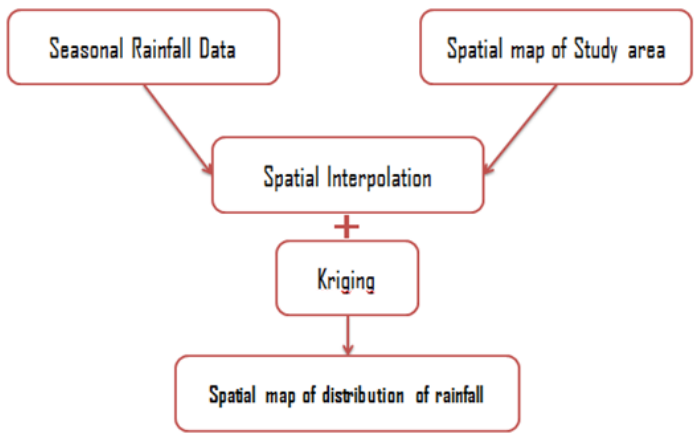

Fig. 3: Methodology for preparing spatial distribution of rainfall map

Geographical information system (GIS) of ArcGIS software version 10.3 was used for preparation of temporal and spatial rainfall distribution maps. Microsoft excel was used for the preparation of rainfall data base and used as GIS input. Spatial interpolation is the technique of utilizing points with well-known values to assessment the values at other points. Kriging produced better results than other interpolation methods such as Inverse Distance Weighted (IDW) and spline. ${ }^{6}$ [Kriging tool in GIS was used to interpolate a raster surface from points using Kriging an advanced geostatistical procedure (Syntax: ArcToolbox - Spatial Analyst ToolsInterpolation - Kriging).] In Kriging, the seasonal rainfall data of each rain gauge stations are given as an input point feature. Where ordinary kriging method and linear semivariogram method was used for interpolation (Fig 3). Percentage Departure of annual rainfall in the district was calculated using normal annual rainfall. The category of annual departures from normal with range and colour code (Table 1) done for 10 years period (2003-2012).

Table 1: Category of departures from normal ${ }^{7}$

$\begin{array}{lll}\text { Category } & \begin{array}{l}\text { Departures } \\ \text { from Normal }\end{array} & \begin{array}{l}\text { Colour } \\ \text { Code }\end{array}\end{array}$

$\begin{array}{ll}\text { LE - Large } & 60 \text { percentage or more } \\ \text { excess } & \\ \text { E - Excess } & 20 \text { to } 59 \text { percentage } \\ \text { N - Normal } & -19 \text { to }+19 \text { percentage } \\ \text { D - Deficient } & -20 \text { to }-59 \text { percentage } \\ \text { LD - Large } & -60 \text { to }-99 \text { percentage } \\ \text { Deficient } & \\ \text { No Rain } & -100 \text { percentage } \\ \text { No Data } & \text { Data Not Available }\end{array}$

\section{Results and Discussion}

Normally the climate of the district is cold and wet. Spatial variability of climate can be large due to the precipitation ranging from $<1000 \mathrm{~mm}$ up to $>4000$ mm. ${ }^{8,9,10}$ The Mean annual rainfall, Mean North East Monsoon (NEM) rainfall, Mean South West Monsoon (SWM) rainfall, Mean summer and winter rainfall, Mean rainfall distribution, spatial distribution and Percentage Departure of annual rainfall for Tiruchirappalli district are discussed below.

\section{Mean Annual Rainfall}

Tiruchirappalli district has the mean annual rainfall of $695 \mathrm{~mm}$. From 1980 to 2012, the rainfall received was $24 \%$ less than the mean rainfall for almost 19 years. During this period, the following years received rainfall less than $350 \mathrm{~mm}$ viz., 1976 (228 mm), 1980 (289 mm), 1982 (340 mm), 1985 
(322 $\mathrm{mm}$ ). Whereas nearly 23 years received $25 \%$ more rainfall than the mean rainfall especially the following years received rainfall more than 950 mm viz., 1977 (977 mm), 1978 (985 mm), 1979 (1039 mm), 2005 (1247mm), 2008 (981 mm). The maximum rainfall $1247 \mathrm{~mm}$ recorded in the year of 2005 as well as the low amount of rainfall recorded in the year of $227 \mathrm{~mm}$ recorded in the year of 1976 (Fig 4). Tiruchirappalli district is part of the Cauvery Delta Zone (CDZ) in Tamil Nadu out of seven Agro climatic zones. In twentieth century Cauvery River basin has faced insignificant decrease in annual rainfall. ${ }^{11}$

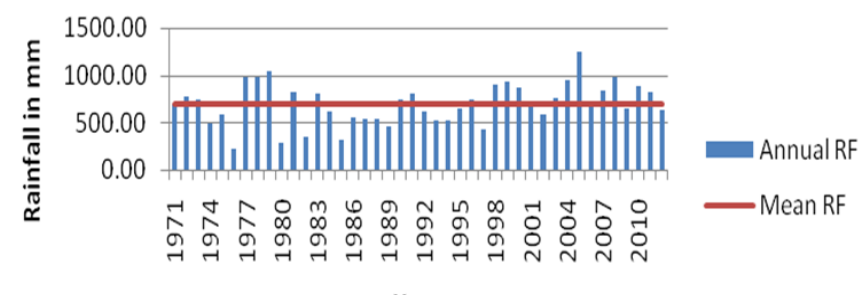

Year

Fig. 4: Annual and mean rainfall of Tiruchirappalli district

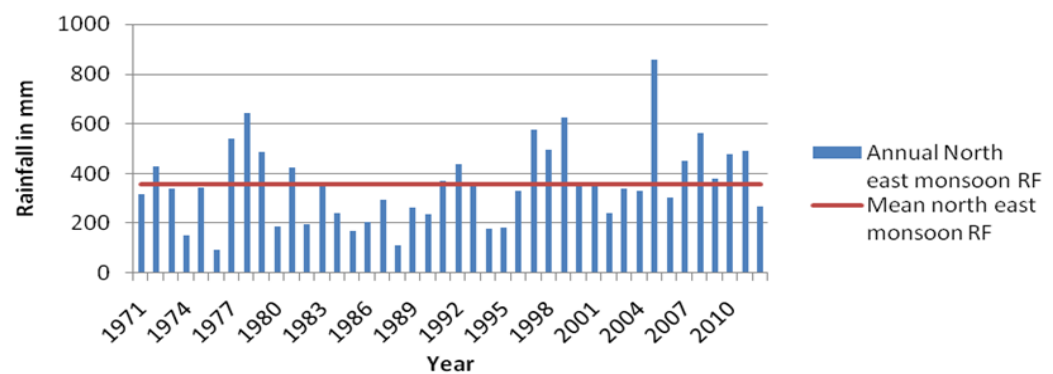

Fig. 5: Annual and mean north east monsoon rainfall of Tiruchirappalli district

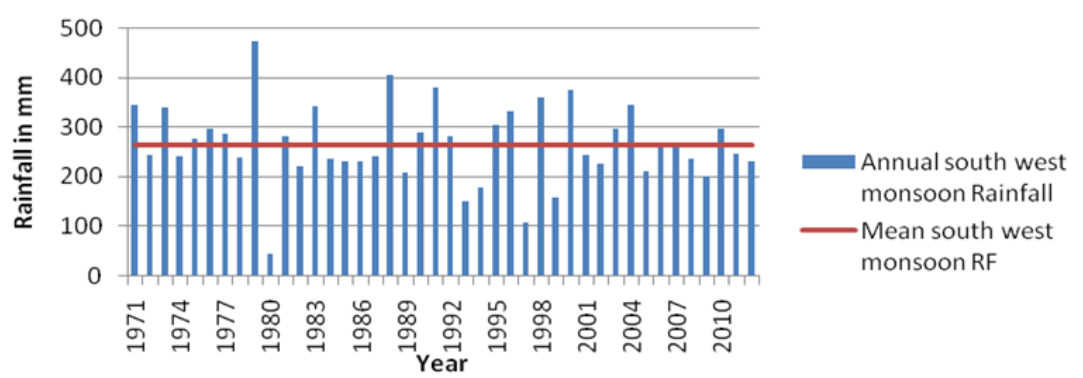

Fig. 6: Annual and mean south west monsoon rainfall of Tiruchirappalli district

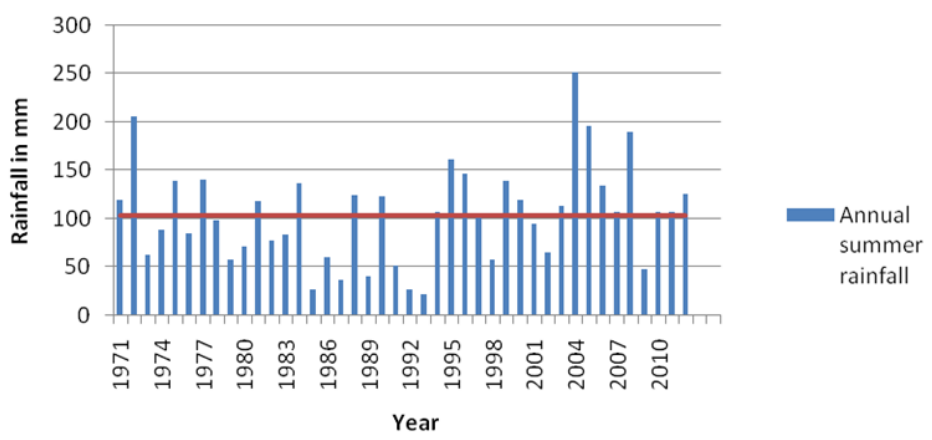

Fig. 7: Annual and mean summer rainfall of Tiruchirappalli district 


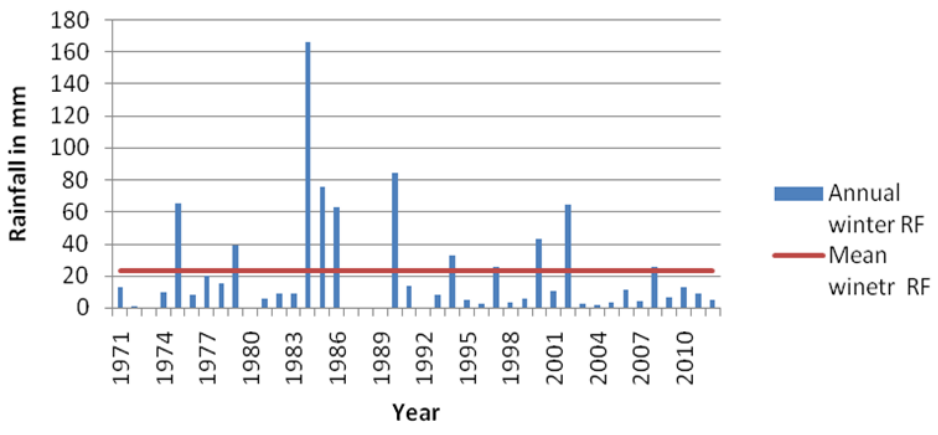

Fig. 8: Annual and mean winter rainfall of Tiruchirappalli district

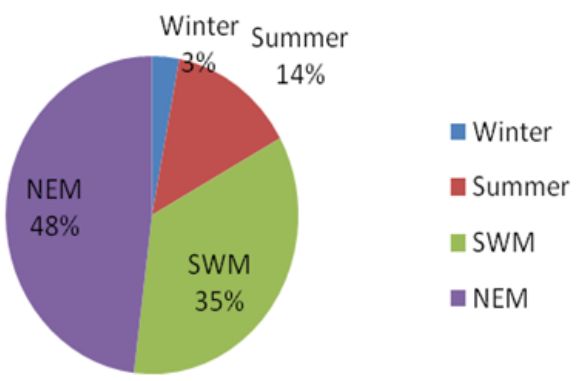

Fig. 9: Mean rainfall distribution of the district (Monsoon wise)

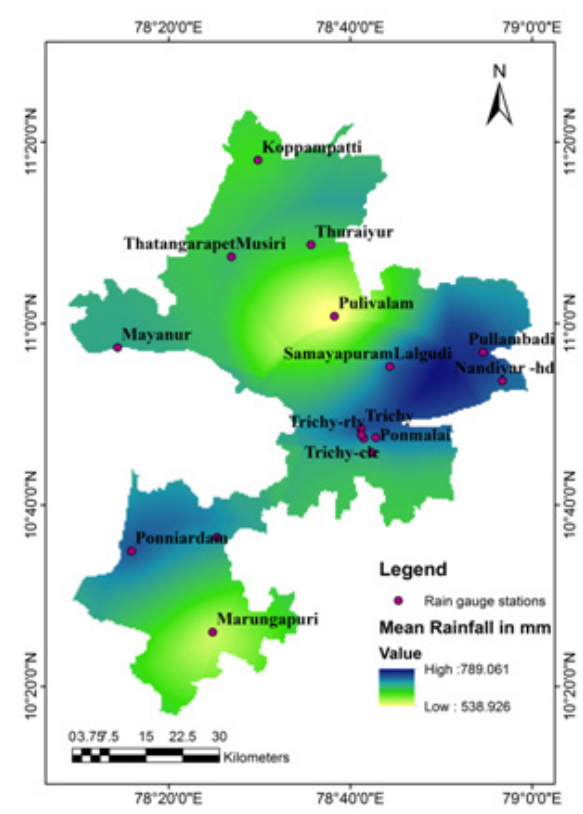

Fig. 10: Spatial spread of Mean annual rainfall of the district

\section{Mean NEM Rainfall}

The mean NEM rainfall of the district was 358 $\mathrm{mm}$. From 1980 to 2012, the rainfall received 31
$\%$ less than the mean north east monsoon rainfall for 18 years. During this period, the following years received rainfall less than $200 \mathrm{~mm}$ viz., 1974 (151 mm), 1980 (189mm), 1982 (197 mm), 1985 (170 mm), 1988 (112 mm), 1994 (180 mm), 1995 (181 mm). From 1980 to 2012, 24 years received $27 \%$ more rainfall than the mean. Out of which 1977 (542 mm), 1978 (641 mm), 1999 (624 mm), 2005 $(858 \mathrm{~mm}), 2008(561 \mathrm{~mm})$ years received rainfall more than $500 \mathrm{~mm}$ (Fig 5).

\section{Mean South West Monsoon Rainfall}

The annual and mean SWM precipitation of Tiruchirappalli district is illustrated in Fig 6. The mean South West Monsoon rainfall is $264 \mathrm{~mm}$. From 1980 to 2012 , in 20 years rainfall received was $23 \%$ less than the mean. In this, the following years received rainfall less than $150 \mathrm{~mm}$ viz., 1980 (42 mm), 1993 (148 mm), 1997 (106 mm). From 1980 to 2012, 22 years received $(22 \%)$ more rainfall than the mean. In this, 4 years received rainfall more than $350 \mathrm{~mm}$ viz., 1979 (472 mm), 1988 (403 mm), 1991 (378 mm) and 1998 (358 $\mathrm{mm})$.

\section{Mean Summer Rainfall}

The mean summer rainfall is $104 \mathrm{~mm}$. From 1980 to 2012 , in 19 years the rainfall received $(41 \%)$ less than the mean summer rainfall. During this period of years received rainfall less than $50 \mathrm{~mm}$ viz., 1985 (27 mm), 1987 (37 mm), 1989 (41 mm), 1992 (27 $\mathrm{mm}), 1993$ (22 mm), 2009 (48 mm). From 1980 to 2012, 23 years received more (35\%) rainfall than the mean summer rainfall. Out of which the following years received rainfall more than $150 \mathrm{~mm}$ viz., 1972 (206 mm), 1995 (162 mm), 2004 (252 mm), 2005 (196 mm), 2008 (189 mm) (Fig 7). 


\section{Mean Winter Rainfall}

The annual and mean winter rainfall of Tiruchirappalli district is illustrated in Fig 8 . The mean winter rainfall is $23 \mathrm{~mm}$. From 1980 to 2012, the rainfall received less than the mean winter rainfall for 31 years and 11 years received more rainfall than the mean winter rainfall.

\section{Season Wise Distribution of Mean Rainfall (1971-2010)}

Tiruchirappalli district received $48 \%$ rainfall during NEM; $35 \%$ during SWM; $14 \%$ during summer and
$3 \%$ in the course of winter season out of annual rainfall (Fig 9). North East Monsoon contributed more in rainfed agricultural areas of the district followed by SWM.

\section{Spatial Spread of Rainfall}

The spatial spread of rainfall map was generated using Kriging interpolation technique of ArcGIS software. The ordinary Kriging method is one of the interpolation technique widely used, which plays an important role in interpolation and mapping precipitation data in any region. ${ }^{12}$
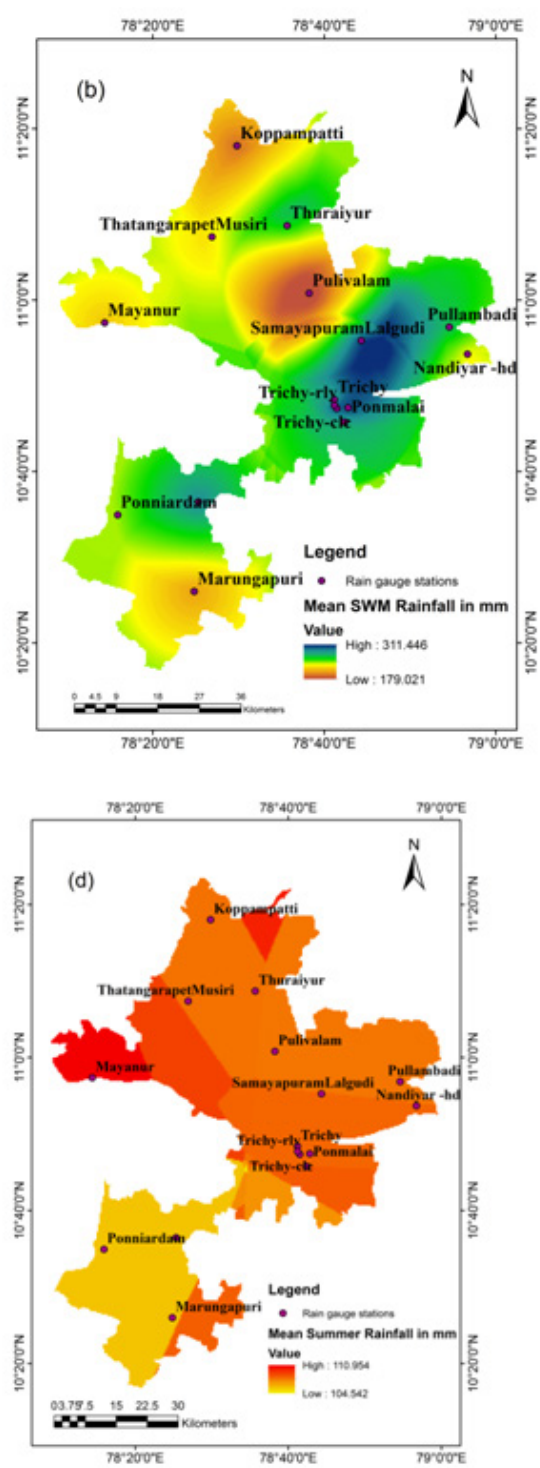

Fig. 11: Spatial spread of Mean NEM (a), SWM (b), Winter (c) and Summer (d) rainfall of the Tiruchirappalli district 
Spatial distribution of mean annual rainfall map clearly indicated that the North East part of Tiruchirappalli district received maximum rainfall compared to South West parts of Tiruchirappalli. While South East and central part of Trichy received moderate to low rainfall during the period 19712012 (Fig 10). Spatial map of distribution of rainfall (season wise) is illustrated in Fig 11. During NEM and SWM, North East part of Tiruchirappalli district such as pullambadi, Lalgudi and nearby area received maximum rainfall. In winter season Manappaarai and Vaiyampatti region received more rainfall where as Thottiam and Mayanur area received more rainfall in summer season.

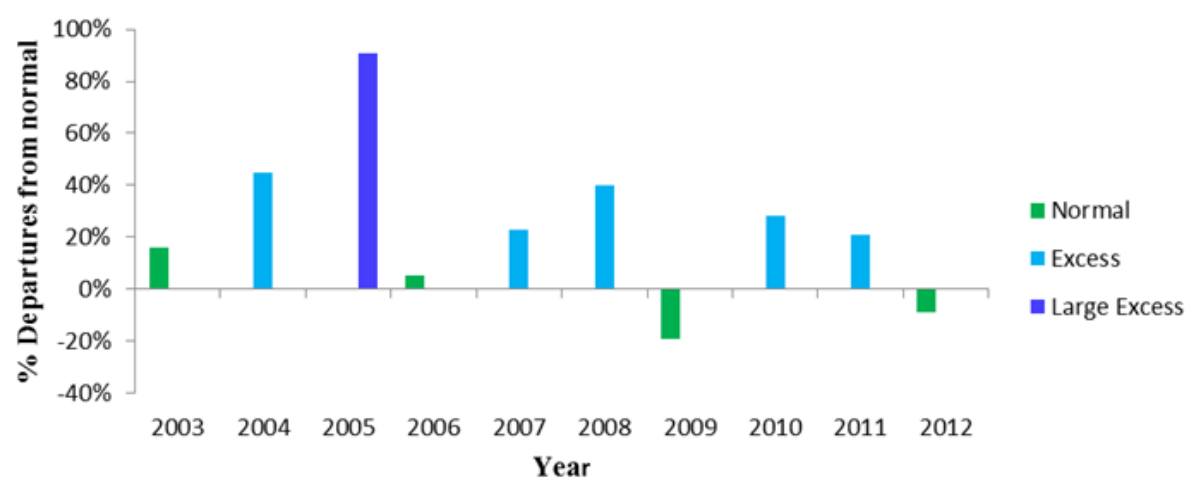

Fig. 12: Percentage Departure of annual rainfall in the Tiruchirappalli district

\section{Percentage Departure of Annual Rainfall}

Percentage departure can be calculated through difference between the observed (annual rainfall) and predicted value (normal annual rainfall) and then divided by predicted value. If the percentage departures from normal is $20 \%$ to $59 \%$ it is under the category of excess. If the percentage departures from normal ranging from $-19 \%$ to $19 \%$ it is under the category of Normal and more than $60 \%$ means it is large excess category. During the years 20032012 the percentage departure of annual rainfall was under the category of excess in 2004, 2007, 2008, 2010 and 2011, normal was in 2003, 2006, 2009, 2012 while only year 2005 was under the category of Large excess (Fig12). Out of 10 years, there is no year was under deficient category. Percentage mean departure from normal was 25 during 2003 -2012 in the district.

\section{Conclusion}

Rainfall characteristics of Tiruchirappalli district were analyzed in the present study with the help of spatial and temporal data of GIS. It has the maximum rainfall of $1247 \mathrm{~mm}$ recorded in the year of 2005 while minimum rainfall of $227 \mathrm{~mm}$ recorded in the year of 1976 . Tiruchirappalli district has the mean areal precipitation of $695 \mathrm{~mm}$. The mean north east monsoon rainfall was $358 \mathrm{~mm}$, which is $26 \%$ more than the mean south west monsoon rainfall
(264 mm). Tiruchirappalli district secured with $48 \%$, $35 \%, 14 \%$ and $3 \%$ of rainfall in the four seasons like NEM, SWM, summer and winter season respectively out of annual rainfall. The north east parts of Tiruchirappalli received maximum rainfall compared to south west parts of Tiruchirappalli. The south east and central part of Tiruchirappalli receives only moderate to low rainfall. The percentage departure of annual rainfall of the district is falling under the categories of normal, excess and large excess. The developed spatial distribution rainfall maps will be helpful to form a crop plan to increase the agricultural productivity of Tiruchirappalli district.

\section{Acknowledgment}

The authors are grateful to Water Technology Centre, Tamil Nadu Agricultural University for carrying out this study. The data provided by the State Ground and Surface Water Resources Data Centre, WRD, PWD, Go TN is hereby acknowledged.

\section{Funding}

There is no funding or financial support for this research work and it is part of the student research project.

\section{Conflict of interest}

All authors are not having any conflict of interest. 


\section{Reference}

1. Precipitation. In: Subramanya K. Engineering Hydrology. $3^{\text {rd }}$ edition. The McGraw Hill companies; 2008. 13-58.

2. Alaka Gadagil. Annual and weekly analysis of rainfall and temperature for Pune: a multiple time series approach. Inst. Indian Geographers. 1986; 8(1).

3. Khadeeja Priyan. Spatial and Temporal Variability of Rainfall in Anand District of Gujarat State. Aquatic Procedia. 2015; 4:713 -720 .

4. Tripathi S. K. Rainfall Analysis for Cropping Planning: A Lesson from Uttarakhand, Journal of Applied Hydrology. 2009; XXII (I):42-54.

5. Alaguraja Palanichamy. Assessment of Rainfall and Groundwater for Agriculture of Tiruchirappalli District, Tamil Nadu, using Geospatial Technology. International Journal of Latest Technology in Engineering, Management \& Applied Science. 2016; V (VIII):40-52.

6. Julie Earls and Barnali Dixon. Spatial Interpolation of Rainfall Data Using ArcGIS: A Comparative Study. Proceedings ESRI, University of south Florida St. Petersburg. 2007.

7. Yadav B.P, Ashok Kr. Das, Singh K.V and Manik S.K. Rainfall Statistics of India. Hydromet Division, India Meteorological
Department, Ministry of Earth Sciences, Government of India. 2017.

8. Hofstede R, Segarra P, Mena P.V. Los Paramos del Mundo. Global Peatland Initiative/NC-IUCN/EcoCiencia, Quito.2003.

9. Luteyn J.L. Paramos: A Checklist of Plant Diversity, Geographical Distribution and Botanical Literature. The New York Botanical Garden Press, New York.1999.

10. Sarmiento G. Ecological features of climate in high tropical mountains. In: Vuilleumier, F., Monasterio, M. (Eds.), High Altitude Tropical Biogeography. Oxford University Press, Oxford. 1986:11-45.

11. Sushant S, Balasubramani K, Kumaraswamy K. Spatio-temporal Analysis of Rainfall Distribution and Variability in the Twentieth Century, Over the Cauvery Basin, South India. In: Ramkumar M., Kumaraswamy K., Mohanraj R. (Eds) Environmental Management of River Basin Ecosystems. Springer Earth System Sciences. Springer, Cham (2015). https://doi.org/10.1007/9783-319-13425-3_2

12. Huseyin cagan kilinc. Estimation of Rainfall Distribution Map of Turkey By IDW And Kriging Interpolation Method. American Journal of Engineering Research (AJER). 2018; 7(6): 238-241. 